\title{
Social Justice: History, Purpose and Meaning
}

\author{
Allan C. Ornstein ${ }^{1}$
}

Published online: 27 October 2017

(C) Springer Science+Business Media, LLC 2017

Social scientists study social mobility in order to ascertain the relative openness or fluidity of a social structure. They are interested in the difficulties different persons or groups experience in acquiring the goods and services that are valued in the culture and may be acquired through unequal contributions.

In ascription societies, the stratification system is closed to individual mobility because prestige (or status) is determined at birth. The amount of education one will receive, the occupational status one will enter, one's income and one's whole lifestyle cannot be changed. In an open-class society, although people start with different advantages, opportunities are available for them to change their initial positions. The life chances of a welfare recipient's son born in the slums differ considerably from those of a banker's son born in the suburbs. Although the playing field is tilted and stacked against the slum child, in an achievement-oriented society, the former can achieve as much or more than the latter.

The emphasis on vertical social mobility in the American social structure is one of the most striking features of our class system - and the basis for what we often call the "American dream." Kurt Mayer, in Class and Society, puts it this way: "The United States has placed greater emphasis on social mobility than any other large nation in modern times. Americans have firmly proclaimed the idea of equality and freedom of achievement and have acclaimed the large numbers of individuals who have risen from humble origins to positions of prominence and

This article is dedicated to Sophia and Carissa who will eventually come to understand the meaning and implications of the article below.

Allan C. Ornstein

allanornstein@yahoo.com

1 School of Education, Sullivan Hall, 5th Fl, St. John's University, 8000 Utopia Parkway, Queens, NY 11439, USA affluence." The believe in opportunity is strongly embedded in the American culture, a view promulgated in the stories of Horatio Alger and songs like "Rags to Riches."

Most Americans would accept the above analysis of mobility and opportunity. But that's not how the world works: For some 5000 years of recorded history, until the late eighteenth century, the ordinary person (nearly $99 \%$ of the populace) has lived on the edge of starvation, slightly above subsistence level, with no rights and no justice.

\section{The Ancient World}

From the beginning of civilization to the American Revolution, the monarchs, priests, and warlords (later the nobility class) ruled the world. Economic growth would enhance the wealth of those who were already rich or powerful; the masses were little more than slaves, serfs, peasants, or chattel-who worked until death or disablement and whose life expectancy was 30 to 35 years - depending on the century and society. Behavior was grounded in appetite, or desire and selfinterest. Those with power and wealth sought to retain their position, and there was minimal or no opposition by working and subordinate people who lacked the ability to oppose what was perceived as the natural order. Nothing could be done to change it, and that is how the world existed for centuries. The idea that humans have rights is a relatively new concept - not more than 350 years old.

Heredity privilege governed society and those fortune by birth were expected to benefit at the expense of the working masses who were limited by their unprivileged birth. Intelligence or any other human strength had to be extraordinary before it could count for much in comparison to heredity privilege. Each person, relying on traditions of birthright and background and his own resources, labored within a fixed, 
stratified society. The rewards went to the rich and powerful, while the ordinary person worked from dawn to dusk and lived in poverty and squalor. The superiority of civilization over barbarianism did very little to change the miserable conditions of working people. In short, life for the common person was brutal and short. The masses were controlled by those who ruled. Might made right; there was no rule of law. Human rights or social justice were nonexistent. Plunder and rape, starvation and war, characterized the flow of events.

With the exception of the Greeks and Romans, all the great civilizations of the ancient world would fall under the aristocratic rule of monarchs and emperors, supported with an entrenched and corrupt nobility or property class, where the mass were either slaves, manual laborers or peasant farmers who toiled until their death. The vast majority of people were nothing more than disposable units of production kept alive at the subsistence level. Their function was to keep the system running. Their wages or economic rewards would mainly cover the cost of their daily existence so they could produce the next generation of children who would be laborers or till the land. People lived by war and conquest and developed first from warlike families which grew into clans and tribes, cemented by blood, which then grew into small villages and settlements and then city-states and monarchies and kingdoms.

The warlords who commanded armies were paid by monarchs in gold, property and for titles in exchange for their loyalty. These warring leaders obtained heredity titles and land, and thus transformed into the "gentry" or nobility class. They gained recognition for possession of goods and people, as well as military valor. The masses - whether they were slaves or serfs, peasant farmers or laborers - surrendered their rights and freedom to those who could provide security and protect them from plunder and facilitate their survival needs. People were willing to live in a society where government had a heavy hand, even in an authoritarian order, so long as they knew they could live in relative safety; their goal was not to be raped or brutalized by stronger people and roaming armiesand to have food on the table.

What we are describing here is a gloomy and brutal world - and why people are often willing to give up their freedom, including their rights and opportunities. Civilization brought a degree of peace and security for the masses, compared to the age of barbarianism. In a nut shell, a social order accompanied by a freedom of fear, plunder and rape takes precedence over economic possessions and prizes and even human rights. In a Hobbesian world, there is no moral high ground. People of power and property seek their own self-preservation and combine by marriage and alliance to obtain more power and property. They act as a force for change at the expense of less powerful people who are just trying to live day-to-day and feed themselves.

\section{Our Western Heritage: The Greeks and Romans}

Now ancient Greece and Rome were a slightly different story. Their development was a variation of this theme, from barbarianism to civilization. But their political system was cemented by human agreement. Citizens had a political voice among ruling elites, rather than the simple bloodline and hereditary succession and the complete domination of the masses in the ancient civilizations that preceded them.

In the Greek era, a distant mirror of the politics of our own age, it was believed that the citizens had certain rights and civic duties - and could argue for or against any proposition in the marketplace of ideas - the courts, the public arena, etc.

Plato's Republic fashioned a plan for a perfect state ruled by an intellectual elite of philosopher-kings - not a money elite or hereditary aristocracy. Society existed to cultivate truth and virtue in its inhabitants, based on assumptions that only knowledgeable men should rule and that all inhabitants who had basic rights should contribute to the general welfare according to their intellectual capacity and particular aptitude. Education, not privileged birth, was the major vehicle for defining the social and economic relations of the residents in Plato's Republic. The educational system played a selective role as it rated intellectual aptitude and sorted children into future categories: philosopher-kings, auxiliaries and soldiers, and workers. Once assigned to a class, individuals received the appropriate education assigned to their social-economic position - and mobility was frozen. Plato believed that each class would fulfill a necessary function and contribute to the common good. Such a society, he believed, would be harmonious.

Even now, both liberal and conservative thinkers, love to make comparisons between the ancient Greeks and our Western heritage. To some extent, we are all Greeks - at least in terms of our culture and political beliefs. Americans, I believe, are more likely to agree with a dead Greek poet or philosopher than the best known lawyers or social scientists of the modern world to bolster an argument or advocate a point of view. We think the ancient scholars from the Greek islands spoke with less spin (and more virtue) than modern politicians and policymakers. This view is especially seen in the writings of traditional educators and philosophers who advocate the classics and great books approach to education.

It would be nice to envision America as the sole heir of Athens - where democracy first flourished - and to be a champion of moral virtue and humanitarianism. But we are also Romans. The same land that gave us Cierco and Virgil, and forged the foundations of our Republic, forced humans (gladiators) to square off against each other and against wild animals. It is true that Cierco had climbed from relatively humble surroundings to the highest offices of the Roman Empire. With Cierco's death, however, more precisely his assassination, the Empire lost its most staunchest legal advocate and political conscience-and soon fell under the 
autocratic rule of a series of notorious and corrupt emperors who brought ruin and decay to Roman society.

In his last years of life, Cierco warned the Senate about patrician greed and class warfare, and to shame his colleagues in the Senate about growing inequality between the patrician and plebian classes. The orator's words ring loud today: "A belief has become established-and harmful to the Republic...that these courts, with you senators as the jury, will never convict any man, however guilty if he has sufficient money." We must also read Tacitus in terms of "diminutive rivalries." Strong men will trample weak men in war, politics or business affairs "as long as there are prizes to contend for which move their avarice or their ambition."

We overlook the fact that Greek and Roman society, like all the previous ancient societies, were built on the backs of slaves, and only a minority of Greeks and Romans had the rights and privileges described by the great Greek and Roman philosophers. We love to trace our philosophical thoughts to Greece and Rome, but we ignore that both civilizations believed in a government run by the well educated and property class - nothing more, if I may add, than an oligarchy - and what later would be called the European nobility.

The expectation remained in Europe, and the rest of the world (except America), that the masses were destined to live at the brink of starvation, famine and disease. This was the way it had been since the dawn of civilization. The human condition was characterized first by chaos and then miseryas the strong plundered the weak. Economic life was a struggle, pure and simple. Life was brutal and short, void of human rights or justice.

The idea of a social contract between government and the people or that people had natural rights and could live a descent life, with opportunities for improving their condition, was considered illogical and contrary to the norms of society. It violated the customs and traditions of the relations that bounded the Church and the faithful, Prince and subject people, property owner and peasant, master and servant. Equally disturbing was that in the normal course of events ordinary people did not expect anything but misfortune and privation, nor did they expect significant improvement in their social status or standard of living. From the beginning of recorded history, the workers and weaker members of society expected to be pressed down and exploited. The majority opinion was that the passions of men did not conform to the ideas of reason, fairness or justice; hence, there was the uncritical acceptance of the selfish nature of man - and that the strong would prey over the weak.

A slightly more optimistic current took hold in America, spearheaded by political leaders who were influenced by the humanitarian ideas of the Age of Enlightenment. Still, the concepts of slavery and indentured servants existed and were woven into the social order during the colonial and postcolonial era. The platitudes of moral behavior, the common good, and helping the less fortunate (Kant's doctrines), the natural rights of men (Voltaire's idea), a social contract between government and the people (Rousseau's dictum), the notion of "life, liberty and property" (Locke's statement) and the substitution of property for "pursuit of happiness" (Jefferson's modification) were all abstract ideas that went against the tide of opinion and the dictates of reason prior to the American Revolution.

In Europe Locke, Voltaire, and Rousseau were considered extremely radical among their contemporaries, promoting ideas based on a false and untenable conception of human nature. In some ways they were the mouse that roared. Few people of power and property took them seriously, but eventually their writings began to seep into discussions at the taverns and coffee shops of Geneva, London and Paris. Despite the American and French Revolution, the upper classes in both the Old and New World did not subscribe to these doctrines, nor did they have faith and/or respect in the common people or the rights of the people. In fact, Thomas Jefferson was considered a traitor to the class interests of Southern plantation owners and northern bankers, similar to the way Franklin Roosevelt more than 150 years later was viewed by the Brahmins and business class when he implemented civilian work programs, unemployment insurance and Social Security for Americans during the Great Depression.

During the Industrial Revolution which started in merryold England around the time of the American Revolution, special skills and special abilities of people resulted in slightly higher wages than the norm. But the fixed economic system and social traditions of prior societies directed toward the past remained intact, rather than toward a future which men themselves might shape. The amount of people who rose from pittance to what might be called middle class was miniscule in numbers compared to the masses who remained poor and destitute.

Actually, the Industrial Revolution increased inequality between the mercantile and manufacturing class with the labor and working class because the vast portion of wealth attributed to economic growth went to the economic elite, not the masses. To be sure, a rising tide does not always lift all boats in the water, not when the surrounding environment or custom is fixed and not when a person's position in society is considered from a static position as it was viewed for centuries. We are not all in the same boat, as Jack found out the hard way in the movie Titanic. No doubt the new industries allowed a tiny number of entrepreneurial people to accumulate capital and equipment. Thus a few people endowed by nature, that is by strength and cunning, were able to take advantage of the fruits of their power and abilities.

This new concept of competition and productivity led to nineteenth century Darwinist thinking, that is "survival of the fittest" and Herbert Spencer's dictum, the "law of the jungle." Such ideas could be viewed as an outgrowth of the ancient 
world which set man against man in the pursuit of power, prestige and wealth - and left the masses to fend for themselves relative to their state of nature. This idea was modified in the New World, whereby common people could successfully compete and fit well into the American landscape, largely because of the frontier experience, the abundance of free land and natural resources, the constant flow of immigrants, and the long-favored notion of progress and change. Moreover, there was no history of warlords, family lineage or bloodlines; the land had not been carved up by centuries of war and strife, by warlords who later became known as Dukes, Earls, and Barons.

The point is that in the U.S., there was so much land and resources for the taking that it did not create a zero-sum game between the power elite and the common person; the people with new powers and property allowed the masses to accumulate their own riches because there was so much land available for anyone who was willing to risk the unknown and work hard. "Survival of the fittest" eventually blended into the folklore of the West and later the customs of the Gilded Age. The picture of the self-made man of the nineteenth century, epitomized by the robber baron, warped into Ayn Rand's book, Atlas-Shrugged, published in 1957. In the twentieth century, Rand's image of the self-reliant, egotistical person rejected the idea of the common good, altruism and helping less fortunate people. In both centuries, however, the capitalist system evolved from the brutal conditions of the ancient world: The strong survived and the weak barely existed or perished. Life was a struggle, a part of nature - where every group, every animal or human was always in a ceaseless struggle with its environment and its species.

Material wealth at the expense of "the herd" or ordinary people was common. Greed was and still is considered good; it's the fuel or engine that supposedly drives the economy. There is little concern for the working person - as well as for the weak, the old, the disabled, etc.

\section{The Promised Land}

But America is the land of opportunity, where peoples' aspirations and dreams come true, where ordinary citizens have rights guaranteed by law. Immigrants fleeing from oppressive governments or economic hardship can start a new life and have multiple chances to succeed.

Keep in mind our history: The ideas of the Enlightenment, when transported across the ocean, prevailed over authoritarianism and theocracy. Thank the heavens that a group of middle-aged rebels were willing to put their lives on the line, and thank Thomas Jefferson who wrote the Declaration of Independence and said the right words at the right time and provided the framework that gave us the natural right to establish the rights of people and separate the church and state.
Of course, the English aristocrats and conservatives did not see it the same way. Harping on the vulgarity and clumsiness of their former colonialists, one English novelist some 50 years ago summed up the American revolutionists as "malcontented" children and Americans in general as "cowards" who were "almost all the descendants of wretches who deserted their legitimate monarchs for fear of military service."

The doctrine of natural rights of man, "the right of life, liberty, and the pursuit of happiness," the idea that "all men are created equal," a belief in "a government of the people and by the people," the rights to own land, the rights to assemble, to protest and express opinions, the devotion to education and self-improvement for plain people - all these principles that we take for granted today did not come easily and required an uphill battle of ideas and for the minds of people. Liberty and freedom are not given to a country, but it is a result of hardwon struggles, a belief in the rights of all people and the protection of minority rights. It is not easy to transcend religion in a deeply religious country as ours, and to allow secular laws to prevail. It is not easy to overcome the power of the rich and allow the people to govern, whereby the rich ultimately have to answer to the people and where the rule of law prevails.

In the U.S. capitalism would be encouraged to expand, but there would be no feudal class, no peasant class, no serfs perpetually indentured to the monarch or nobility class. There would be genuine reform in which people of different classes and occupations would come nearer in speaking the same language and have similar opportunities than anywhere else in the world. The reward system based on inherited privilege and power would be curtailed so that the nation would not have the same "winners" and "losers" from one generation to the other. The ultimate question comes down to what we should do so all Americans could thrive. The answer was to use government to bring about reform so everyone had the potential to prosper. The country would have to work for everyone! A government of the people and for the people was the only counter force powerful enough to curtail corporate power and abuse.

So we are the lucky ones. Over the course of nearly 250 years, this nation has grown from a small cluster of colonies with a ragtag collection of people and a makeshift army, to a free, mighty, and wealthy nation - the most influential one in the history of humankind and on the present world stage. How was this possible? Does it boil down to accident, luck, or design?

I cannot give you a precise answer-why we are the chosen ones, or the lucky ones. The answer, to some extent, comes from the heart, from the feelings and emotions of plain people, immigrant people, and working people who inhabit our landscape and who know they are free: Free from the yoke of oppression, free from the sword, whip and boot - and therefore strive, innovate, and invent. Despite that we are a nation of many nations, with different customs and folklore, we all 
speak the same language as free men and women and breathe the same free air. The answer also comes from all the people around the world who clamor to come to our shores to escape their nations' rulers, tyrants, and oligarchies, to find that pot of gold that can only be found in the New World. Here common people can fulfill their dreams. Here justice has a chance to prevail.

James Weaver, a Populist philosopher at the turn of the twentieth century, identified with the Founding Fathers of 1776 and put it this way: "Throughout all history we have had ample evidence that the new world is the theater upon which the great struggle for the rights of man is to be made," Or, could the answer simply be what Otto von Bismarck, the Prussian chancellor, once muttered? "God has special providence for fools, drunks, and the United States of America."

Alex de Tocqueville, perhaps the most influential visitor and profound observer of America, put it in more realistic terms in 1835: Whereas a "permanent inequality of condition prevailed" in the Old World, where the social conditions tended "to promote the despotism of the monarchs and ruling class on the masses," the principle of democracy prevailed in the United States. Some 175 years later, another foreign gentleman, this time an immigrant from the far-off land of India, Dinesh D'Souza (someone much more conservative but just as idealistic as Weaver and de Tocqueville) commented: "America is a new kind of society that produces a new kind of human being. The human being - confident, self-reliant, tolerant, generous, future oriented - is a vast improvement over the wretched, fatalistic, and intolerant human being that traditional societies have always produced and...produce now."

Then there is David Reynolds, a Cambridge historian, who recently wrote a lengthy history of the U.S., entitled America: Empire of Liberty. American contradictions are described between our lofty ideals and practice. He sees the nation as an empire pieced together by war and conquest, much like other empires of the past. But he also sees America as the successful integration of different people from around the world with diverse and innovative thoughts. Faceless and unknown, lacking hereditary privilege and wealth, people come to America seeking a new beginning, a fair chance, and a future that is offered no where else on earth.

The pictures at Ellis Island tell a story: A tale of people clamoring to come to America, some weeping for joy as they passed into the New York Harbor and saw the Statue of Liberty beckoning them - the huddled masses yearning to be free. The American dream is built on the aspirations and achievements of these immigrants risking life and limb to come to our shores, some seeking political asylum, others seeking economic opportunity and/or a new life. Indeed, there is no better way to judge this country, or any country, than by the numbers of people trying to get into it, as opposed to other parts of the world where people are desperately trying to get out of their country.

\section{The Roots of Social Justice}

The notion of social justice is based on the Christian doctrine of helping less fortunate people - the weak, sickly, and oppressed. To be sure, Jesus cared deeply about people. He went out of his way to help people facing injustices. The Bible is full of passages that advocate helping and caring for people. Instead of being motivated by power, pride, or material wealth, those clergy that follow the scriptures find purpose through acts of justice.

Since the 1920s, social democratic governments in Western Europe have reinforced the view that all citizens should be treated equally. Society cannot be fair or just if it has different categories or types of citizenship, such as nobility and the rest of the population, whites as first class citizens and blacks as second class, dominant and subordinate (or oppressed) groups, etc. Inequality must be reduced or eliminated; opportunities for poor and working people need to be expanded; government is obligated to provide free health and education (including college) services; the free market system needs to be regulated by government; labor has the right to organize into unions; resources need to be allocated more equally; and the rich have to pay higher taxes. In short, income and wealth should be redistributed so there is greater opportunity and equality among the populace, and therefore more justice.

Across the Atlantic Ocean, it was and still is considered unwise to associate with Europe's "social democracy" to avoid being labeled as socialists. The word "liberalism" was used in lieu of socialism. When liberal became a derogatory word, the same ideas were expressed as "progressive." Nonetheless, similar ideas were being promogated as part of Theodore Roosevelt's "Square Deal," Franklin Roosevelt's "New Deal," Harry Truman's "Fair Deal," Lyndon Johnson's War on Poverty and "Great Society" and Bill "Clintonomics." The rational behind these policies were discussed in terms of human rights, rooted in the Age of Enlightenment and the U.S. Bill of Rights. Ideally government would be used to bring about reform so that every American could participate in the American dream; government legislation would right the wrongs of history.

Starting in the early 1960 s social scientists began to touch on topics of justice without using or identifying the name. The conversation focused on equality - and issues related to class and caste. Indeed, the 1960s ushered in a period in which the social conscious of Americans burst forth - coinciding with our concern over racial discrimination, poverty, and equal opportunity. Three authors/books stand out during this period.

James Conant, the Harvard University president, was part of the Educational Establishment. In 1961 he published Slums and Suburbs. Slum schools were compared to their suburban counterparts; they lacked resources, experienced teachers, and a relevant curriculum that could meet the needs of their students. Slum schools were in grave physical condition- 
characterized by broken windows, broken toilets, and graffiti on the walls. Conant wrote that the students in the ghetto areas of large cities "either drop out or graduate from school [with minimal] prospects of future education or employment." He argued that youth out of school and out of work was "a menace to the social and political health of the large cities." He went on to coin the word "social dynamite" and warned that if the social/economic situation did not improve in these schools and cities there would be serious consequences. In short, he was predicting the social and racial upheaval that would soon grip the American landscape.

The same year (1961) John Gardner, Secretary of Health, Education, and Welfare under the Johnson administration, wrote Excellence: Can We Be Equal Too? He discussed social issues that later gave rise to equal opportunity legislation and affirmative action policies. Gardner noted that extreme forms of egalitarianism in schools or jobs tended to eliminate both excellence and merit. On the other hand, extreme forms of competition and excellence could create a permanent underclass with the less abled. He tried to draw a middle position, including multiple chances for succeeding and identifying many different forms of talent—not just academic talent. "It takes more than an educated elite to run a complex, technical society." Differences in rewards are accepted so long as people with special abilities serve the common good and do not use them against society, say in robbing a bank. There is also an expectation that society will establish appropriate institutions such as schools and colleges to nurture those differences in abilities and talents, but it must also provide opportunity for people who are not as smart and talented.

The following year (1962), Michael Harrington, who was a socialist writer published The Other America. The book focused on the forgotten, overlooked, and invisible American, that is the poor who he claimed comprised one third of the US population. Harrington's main point was that poverty was no longer cyclical or temporary. The condition was permanent in the midst of general prosperity; it was a travesty in the richest nation of the world that so many Americans were struggling and living day-to-day. Although the book was small in size, it was a major factor in galvanizing nation-wide support for assisting the less fortunate in America. It was crucial in influencing both President Kennedy and Johnson, and led to the subsequent War on Poverty.

In 1971, John Rawls, a Harvard University professor, published A Theory of Justice. He criticized the gap between the highest and lowest paid workers, called for a floor and ceiling in earnings to close the gaps in income, and advocated that the rich pay more taxes. He also asserted that justice must be conceived in terms of fairness and basic moral principles. A social contract was needed to ensure basic rights for the people. Although Rawls' writing was cumbersome and difficult to read, the book was instrumental in getting scholars and pundits to discuss and write about the principles and policies of justice. Eventually, the notion of justice was fused into the US civil rights movement, emphasizing the rights of all people and the moral principles of justice.

\section{The Meaning of Social Justice}

Social Justice means different things to different people. If you are going to speak or write about social justice you will need to have some understanding of what is a democracy, what rights do people have or should have, and how society should provide for less fortunate people. In the pages below, the author identifies 30 basic principles that should be considered as a framework for defining justice (social justice).

1. The history of Western society bends toward social justice. The fight for social justice is incremental and extends over centuries. The interpretation and judgment of social justice depends on who interprets it and who writes the laws of society.

2. Ordinary people can change the course of history by joining a movement. Social justice is a movement for improving the lives of people. You usually get one or two chances in life to join a movement and make a difference. The idea, to paraphrase Aretha Franklin, is to know when the train is coming, to get on board, and to hold your head up high. In short, the fight for social justice takes persistence, guts, and knowing and doing what's right.

3. A fair and just society will encourage democratic principles of equality, opportunity, and mobility. It will also provide a legal framework for human rights (the concept is less than 350 years old), civil rights, and individual rights.

4. Every democratic society must try to reduce the gap in income and wealth among its citizenry. There must be a reasonable floor and ceiling in income and wealth.

5. The floor and ceiling is achieved through some form of monetary redistribution and taxation, as well as by political compromise. But just when you think you have reached some compromise or agreement, the political winds change and you have a new floor and ceiling.

6. In a just society, all lives have equal value, equal opportunity and equal chances for success.

7. A socially just society cannot forget or ignore people in need, nor leave the majority of its people behind. It must put people first - not property nor profits. It must be willing to examine and reexamine its beliefs and philosophy on a regular basis.

8. All groups, including those who define themselves as a political minority (blacks, Hispanics, women, gay lesbians, labor unions, etc.) recognize some bias and discrimination will always exist. But in a just society, the 
bias and discrimination are minimal and minority groups have the same rights as the majority and are able to fulfill their dreams.

9. In a fair or just society, the class structures are fluid in both directions - up and down, from lower class to upper class and from upper class to lower.

10. In a just society, there must be a political and legal framework that protects and enhances the rights of the people. Laws must not be based on partisan or tribal politics, or they will become temporary, but rooted in moral, social, and economic doctrines that provide opportunities and mobility for all people and groups in society.

11. In a just society, individual rights supersede group rights, corporate rights and property rights. Lawyers and judges have elevated status. The ordinary person can find legal protection as well as redress in the courts. The police must follow and obey the laws.

12. For social justice to flourish, the government must be prepared to intervene. A free-market system, without government restraints, leads to greater inequality whereby talented people make large sums of money and average and less than average workers (the common people or silent majority) are paid at best a living wage.

13. A society characterized by a wide income/wealth gap rewards special talent and entrepreneurship. A society characterized by a narrow gap pays descent wages to ordinary people and rewards the working and middle class.

14. Those who believe that a social contract exists between government and its people reject large gaps in income and wealth; such differences reflect the excesses of capitalism. Those who believe in limited government see large differences in income and wealth as a reflection of the success of capitalism.

15. Given a social contract, the government not only protects the people, but also provides revenue for building schools, roads, and bridges; it also provides safety nets and social programs for its disadvantaged populace, including the poor, sick, disabled, and elderly.

16. An innovative and entrepreneurial society will accept large amounts of inequality; a fair or just society will reduce these differences.

17. The people who believe that getting ahead is a matter of perspiration, talent, or enterprise tend to oppose government intervention and redistributive policies, as well as social programs, safety nets, or entitlements. On the other hand, those who believe that "success" is related to inherited advantages, socioeconomic advantages, or worse, being a member of a dominant group (i.e. born white and born in an upper-class family) support redistributive policies and/or reverse discrimination.

18. Those who believe in the Horacio Alger stories of hard work, self-denial, and honor contend that those who are "successful" have earned their money and deserve it. Those who believe that many wealthy people have acquired their money or assets by inheritance or by exploiting the system (Rockerfellers, Goulds, Kennedys, Trump) believe that ordinary people have little chance for "success." That said, social justice has a long road ahead.

19. Those who control capital, property and/or equipment represent the dominant class - and how wealth is created. Mobility and opportunity must exist to the extent that the subordinate class, or more precisely the common people who work for a living, can improve their socialeconomic status.

20. In a just society, those who have the least benefit from those who have the most via charity works, philanthropy, and in fair tax code.

21. Although a dominant and subordinate group may exist in all societies, in a just society, the differences do not lead to institutional racism, class consciousness, or economic warfare.

22. If the assignment of personal responsibility is used to justify inequality of income and wealth, then there is little chance for social justice. Of course, there could be other reasons for the difference in outcomes such as personal characteristics, luck, or making the right choice at the right time. It is fair if people have more money or assets than others if there is equal opportunity for all citizens.

23. Power corrupts; power must be held accountable. In a just society, the people have the ability to peacefully remove their political leaders and elected officials whenever they deem it necessary.

24. For social justice to be part of the fabric of society, the people must be afforded the right and legal mechanism to investigate, impeach, convict and/or jail their political leaders for incompetence, corruption and/or unlawful behavior.

25. Government laws or executive orders that discriminate against specific groups (racial, ethnic or religious), under the guise of protecting the majority of people or preserving a way of life, are morally wrong and usually illegal. In democratic societies, such laws and orders must be challenged and rejected by the people in the courts or legislated bodies of that country.

26. In a fair and just society, people are paid on the basis of the goods and services they produce for the common good. In a society that stresses excellence, people are paid on the basis of supply/demand, the profit they generate or the cost occurred by hiring them. Those who generate profits are paid the most, sometimes hundreds or thousands of times more than those who are considered cost factors. Teachers are cost factors. The idea is for school boards to control the budget and limit salaries. 
27. So long as Americans have the view that the Sam Waltons, Mark Zuckerbergs Michael Jordans and Madonnas of the world, and all their descendants are entitled to all their wealth, because they worked hard, founded highly successful companies, or could shoot a ball through a hoop or entertain large crowds, then the millions and billions they make will continue to create social injustices and economic imbalance - and doom the rest of us to a bleak future characterized by vast inequality.

28. Globalization affects social justice. The market is seven billion people, not just the size of our country. This means a bigger pie for millionaires and billionaires to build their wealth, thus increasing inequality and reducing social justice around the world. In a just society, the majority of people must be committed to a level playing field, and some legitimate form of equality, even if it means that income and wealth will be redistributed to less fortunate people.

29. When two and two is considered to be five (or up is down and down is up), by a majority populace or by those in power, social justice is at risk and/or significantly diminished.

30. Words count. They are the instrument for both reflection and revolution. A just society permits and defends free speech, a free press and the right to protest peacefully. It recognizes and supports poetry, plays, songs, speeches and film, as well as the publication of newspapers, magazines and books as essential for the health and vitality of society. Words can be used for waging war or for healing.

\section{Conclusion}

Consider that the rich and powerful have always kept the masses in a subordinate position, thus curtailing the opportunity for the majority populace. Only in recent times, with the rise of democratic governments in Western society do the common people have a chance to curtail the dominant class (the rich and powerful) by voting at the ballot box, as well as a chance to reach for the stars and fulfill their own dreams. With the twenty-first century unfolding in the U.S., there should be continuous pressure to increase equality and redistribute income and wealth.
The commitment to provide a fair chance for everyone to succeed and develop their abilities and talents remains central to the national creed for the vast majority of Americans; this is what distinguishes us from the rest of the world. Virtually no one in the U.S. favors equal distribution of income for it would discourage hard work, risk taking and innovation. Some form of inequality, based on abilities and talent, is the price we pay for a dynamic economy and the right for each person to retain the benefits of his or her labor, capital investment or property. The idea is not to focus on the outcomes of inequality, but to address the reasons for inequality - and what can be done to improve the human condition.

It is doubtful if inequality of income and wealth can be reduced simply by education, because the gap between the rich and the rest of us is so great and continues to grow wider. A moral society needs to redistribute income and wealth in order to make its nation more democratic, fair and just. Finding the right mechanism, reaching some compromise, setting limits on income and wealth (a floor and ceiling) is no easy task. Nonetheless, it is essential that we begin to make such changes if most of us in this country are to share in the American dream.

Every generation going forward is obligated to interpret and reinterpret the principles of human rights and justice. Every person in a free society must learn the government's obligations to its people and the peoples' obligation to their fellow citizens and humanity in general. That said, the meaning you find in the above 30 principles of justice depends on your own sense of history and life experiences. The list is not permanent, and should evolve as society changes. The handwriting is on the wall. You only have to see six inches in front of your eyeballs. As the population changes and we become more diverse, educated and tolerant as a nation, we can expect a more liberal or progressive interpretation of justice.

Allan Ornstein is a professor of education at St. John's University. He is a former Fulbright-Hayes Scholar and author of 65 books. His recent books Class Counts: Education, Inequality, and The Shrinking Middle Class (2007), Wealth vs. Work: How 1\% Victimize 99\% (2012), and Excellence vs. Equality: Can Society Achieve Both Goals? (2016) deal with the issues of social justice. 